\title{
Competing Memories and Space in Contemporary Romanian Fiction Written by Women
}

\author{
Lect. PhD, Alina BAKO \\ University "Lucian Blaga" of Sibiu
}

\begin{abstract}
This study is a research suggested by the contemporary man's experience; the contemporary man is at risk of losing the essential points of reference of the cultural, social, political being, and even the position of belonging to humanity, while the mapping of a national literary space, by closely following an algorithm required from the very beginning, becomes a compass in the process of literary/culturall mind-set paradigm redefinition. The nature of most of the definitions of the relationship established between space and literature is metaphorical and they fail to clarify the exact meaning of the terms. In contemporary society, the definition of space, and its derivative products: frontier, limit - become mutations of the nations' identity consciousness, and literature is their witness. These topological under layers, substrata made and remade identities, and they are making and remaking the contemporary ones, while the novel records coherently their cultural flows. The dated binomial of tradition and modernity, under which the Romanian novel developed from the beginning, also included an opposition that cannot be ignored in the contemporary Romanian space. We do not seek to approach a poetics of space, as put by Bachelard, nor do we intend to analyze "the soul of the place"/anima locus, as defined by Butor; what we do seek is to redefine the feminine contemporary Romanian Fiction of the $21^{\text {st }}$ century, when knowledge emanates from literature, history and memory wherein the Romanian space defines a specific manner of writing.
\end{abstract}

Keywords: Romanian Fiction, space, culture, memories, women

Romanian literature after 1989 belongs to a period that includes simultaneously the seeds of the later development, but also the mnemonic remains of a scarring past. The understanding of the evolution of literary forms in the context of a "social schizophrenia" (Todorov 34), which affected Romania, in fragmentary fashion, during the $20^{\text {th }}$ century and from which it has not fully recovered even now, depends on how we relate to the various literary aspects 
and their social ramifications. One of the key-components is linked to contemporary literature written by women and to the modality in which it refers to the legacy of the past, to its subjective retrieval, to the vitality of a narrative that stirs a blend of the sensitivity of reception, through the hard screen of history. When we relate to the essential principles of comparative cultural studies, this is the eighth element necessary for an efficient approach proposed by this type of analysis: "the eighth principle represents the notion of working against the stream by promoting comparative cultural studies as a global, inclusive, and multidisciplinary framework in an inter- and supranational humanities." (Tötösy de Zepetnek Comparative... 5). Prose written by women in post-communism approaches three directions that we can illustrate as follows: the first one includes a recollection of the communist period, starting from pivot-spaces, on which real events, gloved blows of the communist regime, private spaces and outer spaces are grafted. As a necessary reformulation of Romanian fiction, the novel proposed a vision at some points sentimental, elsewhere documentary, meant for an empathizing reader (Iser 34), but also for an inquisitive one who is eager to clarify their recent past. The type of memory that operates here is the individual one, in constant relation to matrices enforced by the political regime. The second direction also stems from a necessary relation with the past, but with a more remote one, in the $18^{\text {th }}-19^{\text {th }}$ centuries; here, the prose writings of Doina Ruști or of Simona Antonescu are more relevant, since they abound in the picturesque of an age reconstructed on the patterns of a collective memory. The third direction is the one of the fantasticonirist novel, which proposes a type of narrative that seeks to abolish the past, by relating to general situations, without connection to the social and political determinations. The first direction is the one that uses history, its terror, since "Applied to art, the notion of history has nothing to do with progress; it does not imply improvement, amelioration, an ascent; it resembles a journey undertaken to explore unknown lands and chart them"/ "Appliquée à l'art, la notion d'histoire n'a rien à voir avec le progrès; elle n'implique pas un perfectionnement, une amélioration, une montée; elle ressemble à un voyage entrepris pour explorer des terres inconnues et les inscrire sur une carte. » (Kundera 28) This is the kind of mapping that we seek in this essay, starting from contemporary feminine prose writing.

The Romanian literary space has undergone obvious mutations, also seen in the occurrence/disappearance of a specific type of narrative. From this point of view, we find that the methodology proposed by Ana Lozano de la Pola 
is both relevant and necessary, in relation to literature written by women and about women. "My proposed framework of comparative feminist studies in comparative cultural studies with regard to gender and genre consists of understanding gender as a constant "work in progress," such as the repetition of gestures, movements, and behaviors regulated by a set of rules and in understanding genericity as a function of textual modelling and performed by the iteration or by the citing of particular rules." (De la Pola 145). This study, however, does not seek to approach a reductionist, feministic view, but to develop a common formula by which the female writers' narratives could be subscribed to a pattern, after 1989. We need to note that our references are to the books of the discussed authors, focusing on how literature improves by writings that add value with theories of corporeality, with gastronomic sensitivities, with recollections of the communist past, with dream escapes, the difference that does not oppose the masculine, but which is another kind of writing literature. From our viewpoint, the analysis of feminism in a literature means its recognition as sole valorizing trait, which is a fundamental mistake that we can find in many of the studies of women's literature (see e.g. Tolan, Wollstonecraft, Friedan, Gilber and Gubar, Moi).

The direction of action, from the intimate/private to the public, was a general tendency in communism, hence the immense, wide spaces that would dominate the architecture of the new cities. Spaces relate to an individual or shared memory, being a modality to express a self deeply anchored in the age's realities. We cannot deny the implications of the ideological in the creation of a state of things that pushes us to classify Romanian literature in before and after 1989. Interdisciplinary research in this field proposes a coherent vision on the relationship of memory, space and literature, by sometimes using even the means offered by neuroscience, relating to how memory may indicate the direction of a narrative form (see Nalbantian). At thematic level, we may establish the main axes of analysis that we will approach, by considering the two core nuclei, i.e. the memory and the space. The space of the action is the Romanian one, with different variations at micro- or macro-level. In Literature after Feminism, Felski found that the element of difference derives from the approached topic related to "life", considering the spaces "where social norms assert themselves as literary forms" (96). Spaces become turntables for the narrative development, which occurs by the use of memory and by the power of recognizing in the text the reader, by the use of the usually traumatic collective memory, which belongs to the age before the Revolution. There have been previous attempts of remembering the past with a focus on prose written by 
women, through fiction (see Gheo and Lungu). We are interested in this occurrence only at an experimental level, since we are able to see in the texts published in the mentioned collection the presence of narrative nuclei that their authors will develop later. Thus, a sort of awakening of consciousness is sparked, which will lead to a number of novels written by known female authors and having as main narrative vein the communist experience. The truth is that any narrative talks about the self, and the authors' personal experiences that we will approach hereinafter occurred in the communist period. We cannot absolutize the use of this kind of memory, as distinctive feature of the narrative, because it falls under the sociocultural patterns of Romanian history. The relation may be operated exclusively from this point of view, and the aspect in which we are chiefly interested i9n this essay is the manner in which memory uses anchor-points in order to render a personal route, which relates to a rediscovery of feminine writing, doubled by the distinct experiencing of a cultural age that marked the evolution of the genre perception in the society. The phrase "feminine literature" is deemed unfounded, Eugen Negrici dismissing this model of interpretation: "The style, the artistic vision and the moral level of the creative act does not supply sufficient reliable arguments for the attachment of a specific sex to literature." ["Nici stilul, nici viziunea artistică și nici planul morale actului creator nu furnizează destule argumente viabile pentru a atașa un sex anume literaturii."] (Negrici 56) However, we need to note that Romanian literature after 1989 converged through various directions of development, and some books written by women went a long way, being valuable both by content and by the intensified sensitivity of the experiences illustrated by the acute reverberations of the woman's soul. As we will show herein, there is a feminine literature, but not one enforced under the laws of feminism, which is excessively included as a criterion of promotion. "For writers such as Herta Muller, Margaret Atwood or Gabriela Adameșteanu, the relativization of one's own gender, linguistic or cultural identity is no longer something to be sought after. And their literature is fueled by a feminine experience of vulnerability and of pain, of worries and of commemoration, of whim and of the daily tragedy, an experience that one cannot ignore" ["Pentru scriitoare precum Herta Muller, Margaret Atwood sau Gabriela Adameșteanu, relativizarea propriei identități de gen, lingvistice sau culturale nu mai este ceva de dorit. Iar literatura lor ajunge să fie alimentată de o experiență feminină, a vulnerabilității și a suferinței, a grijii și a comemorării, a capriciului și a tragicului cotidian, care pur și simplu nu poate fi trecut cu vederea."] (Mironescu 52), noting the core criterion, i.e. the feminine experience that may 
nourish deep narrative writings. The recent years have seen the publication of various studies on the experiences during communism, reflected in literature or becoming a documentary source for it. From the recent Cum citesc bărbații cărțile femeilor/ How Men Read Women's Books, volume coordinated by Lia Faur and Șerban Axinte, to O lume dispărută / An Extinct World (Ion Manolescu, Paul Cernat, Angelo Mitchievici, Ioan Stanomir), Cartea roz a comunismului/The Pink Book of Communism (coord. Gabriel H. Decuble), Născut în U.R.S.S./ Born in the U.S.S.R. (Vasile Ernu) or Tovarășe de drum. Experiența feminină în communism/Female Fellow Travelers. The Feminine Experience in Communism (coord. Radu Pavel Gheo, Dan Lungu), the recent memory of the events experienced before 1989 has filled a consistent page of Romanian literature. Among the novels published in the last 27 years, those filtered by feminine sensitivity occupy a limited space. From among these, we will approach those that, choosing the faithful or sometimes unfaithful memory, borrow times lived in various spaces in order to reconstruct them fictionally. Such a writing is the novel Inocenții/The Innocents, published in 2016, by Ioana Pârvulescu (two other novels were published previously Viața începe vineri/Life Begins on Friday, Viitorul incepe lunil Future Begins on Monday) and which borrows the narrative framework of Brașov, the citadel-city that went through a number of transformations, from the change to its name to Stalin, to the change of street names, all reconstructed by a memory that we may name half-voluntary, since the author confesses that autobiographical aspects are blended with fictional ones. "This "right then" would always come up at the events that would happen in the city Staling. Later, I understood the reason: there are times when personal life is able to fight and even defeat history, to mock and ruffle it. Sometimes, you experience brief moments of bliss in the middle of hell. I liked it a lot when mother or father would tell us about things of the world before our birth. It was almost as if I was reading." [“Acest „tocmai atunci” apărea mereu pomenit la evenimentele petrecute în orașul Stalin. Am înțeles mai târziu de ce: viața personală își permite, în anumite momente, să se lupte și chiar să învingă istoria, s-o ia în râs și-n răspăr. Uneori trăiești câteva scurte momente de rai, în mijlocul iadului. Îmi plăcea deosebit de mult când mama sau tata ne povesteau despre lucruri din lumea de dinaintea nașterii noastre. Era aproape la fel ca atunci când citeam."] The two forms of memory, the personal and the collective one, blend with the actual dates of history. The main character, the youngest, Ana, shifts planes from personal history to History. Validation occurs by experiencing in the community/in the family the social and personal events, because sometimes "to have a history is the same as what it means to have a 
legitimate existence: history and legitimation go hand in hand; history legitimates "us" and not others" (Ashcroft, Griffiths and Tiffin 355) This need of identity, of retrieval after a period dominated by totalitarianism (see Arendt) pushes the character toward approaching topics necessary for a personal and collective definition. Memory also occurs at the level of personal history, through death: "I liked the idea with the tombs. Like everything else new, it carried a tinge of mysterious and terrible. I had not learnt yet what it meant to care about a tomb, because a patch of ground had eaten up someone dear." ["Îmi plăcea ideea cu mormintele. Ca toate noutățile, avea ceva misterios și teribil. Nu știam încă ce înseamnă să-ti pese de un mormânt, pentru că o bucată de pământ ți-a înghițit un om."] (Pârvulescu 122) The use of the painful absence of a being becomes a necessary visit into one's own spirituality. Explanations are offered during the narrative flow and, often, detailed episodes are interposed: "And when you read Homer, you'll find sulfur in the Iliad too, even as sign of Zeus, in fact is has been used as a remedy ever since Antiquity. If there were a hell and there were brimstone, people would bathe there, to cure all kinds of diseases and they would be free of pain! Hell would become a resort". ["Și când o să-l citești pe Homer, o să dai de sulf și-n Iliada, chiar ca semn al lui Zeus, de altminteri e folosit ca leac încă din Antichitate. Dacă iadul ar exista, și în el ar fi pucioasă, s-ar duce lumea la băi, acolo, să-și vindece tot felul de boli și ar scăpa de dureri! Iadul ar deveni stațiune balneară"]. (300) "If we found mold, which would make other moms fly into tantrums, mother said: it's ok, you can get penicillin from it, and moldy cheese is the best there is. She would always link life amazingly to chemistry". ["Dacă dădeam de mucegai, care pe alte mame le făcea să-și iasă din fire, mama spunea: nu-i nimic, obții din el penicilină, și brânza cu mucegai e cea mai bună. Mereu lega viața de chimie într-un mod uimitor."] The house, a space of memory, becomes a character: "I told you, didn't I, that I felt related to our house? It was a family member. Its genetic code had something of all of the people with whom, during my childhood, I crossed paths inside it, of all the people it had hosted for a while. There, they too had intersected their voices, lives, personal histories pulled, not without wounds, from the greater history. The air of the house was their breath, it would move in the same pace with their movement. (...) Its DNA was mixed in mine." ["Ți-am spus, nu-i așa, că eu mă simțeam încă de pe-atunci rudă de sânge cu casa noastră? Era un membru al familiei. Avea în codul ei genetic câte ceva din toți cei cu care, în anii copilăriei, m-am intersectat în lăuntrul ei, cu toți cei pe care i-a găzduit o vreme. Își încrucișaseră și ei acolo vocile, viețile, istoriile personale, rupte, nu fără răni, din istoria cea mare. Aerul casei era dat de 
respirația lor, se mișca în același ritm cu mișcările lor. (...) ADN-ul casei e amestecat într-al meu."] (322-23) or "Our house with an attic and a basement had survived in a world of apartment buildings. It was a heroine. It beat us by a mile in every way. It had experienced two world wars, two earthquakes, a bombing. (...) I find that the house itself, once never-ending, is now short and confining. It's clear that I went from one house to another, and I know what this means: I'm at a different age. Perhaps I've written what I've written because I want to be able to reenter for a while the other house and the only age at which you can visit it." ["Casa noastră cu pod și pivniță supraviețuise într-o lume de blocuri. Era o eroină. Ne depășea în toate privințele. Trecuse prin două războaie mondiale, două cutremure, un bombardament. (...) Casa însăși, cândva nesfârșită, mi se pare acum mică de statură și neîncăpătoare. E limpede că am trecut și eu dintr-o casă în alta, și știu ce înseamnă asta: am altă vârstă. Tot ce am scris aici e, poate, ca să reintru pentru un timp în casa cealaltă și în singura vârstă la care poți s-o vizitezi."] (356)

A specific construction is also present at Simona Șora's Hotel Universal, a novel that focuses instead on a trivial aspect and on a subjective history, linked to a space of Bucharest, the old Teodoraki inn in Gabroveni and on its transformations, with $19^{\text {th }}$ century histories and 1990s memories, from Hotel Universal to the Student Dormitory, witness of tragic events. The fictional is stitched to the documentary aspects. The inn was destroyed in the 1847 fire, after the Revolution the Hotel Universal building, the old Teodoraki inn, became a brothel in the communist period and a location of the State Security. After 1989, it became a student dormitory for the Bucharest University. The documentary data is there, the building is in Bucharest, at 12 Gabroveni Street. "Night after night, Maia would find herself in the balcony of the Universal dormitory room, on the cold cement floor, her legs tucked under herself. She couldn't say who she got there: perhaps after she fell sound asleep, she would climb down the bed, she would move the dusty, stained, mustard colored drapes, open the two high windows and exit on the third-floor terrace, where there would be silence only about two hours a night. Music and voices, broken shouts, yearning grunts and growls of satisfaction could be heard until about three in the morning. I think that's how life was on the ark, Maia would think, in her sleep walking from which she would not wake up until silence would come, and then she would return feeling cold, but refreshed." [„Maia se trezea noapte de noapte in balconul camerei din căminul Universal, stând turcește pe cimentul rece. N-ar fi putut spune cum ajungea acolo: probabil, după ce adormea profund, se dădea jos din pat, trăgea draperiile grele de culoarea 
muștarului, pline de praf si pete vechi, deschidea cele doua uși cu geamuri înalte si ieșea pe terasa de la etajul trei, unde nu era liniște decât vreo doua ore pe noapte. Până spre trei dimineața se auzeau muzici si voci, țipete întretăiate, grohăituri de pofta si mugete de mulțumire. Așa trebuie sa fi fost pe arca, își zicea Maia, in somnul ei somnambulic din care nu se trezea, ca sa intre înfrigurata, dar odihnita, până nu se făcea liniște."] (45) Memories are mixed, the transition from the predicted time to the time narrated by letters occurs without warning: "Where had Vasile found the book? - Diana had asked. At the Secret Stock of the University's Library, the one that had burnt in the revolution, Aliona found herself repeating what she had heard one recent evening at the Old Coffeehouse, where Vasile had met some pals. No one could ever explain in full how Aliona had become in that period the preferred fortune teller in the city." ["De unde avea Vasile cartea? - întrebase Diana. De la Fondul Secret al Bibliotecii Universitare, aia arsa la revoluție, se trezi Aliona repetând ce auzise nu demult, într-o seara, la Cafeneaua Veche, unde Vasile se întâlnise cu mai mulți amici. Nimeni n-a putut explica vreodată până la capăt cum ajunsese in acea perioada Aliona cea mai căutata ghicitoare din oraș."] (89) The hotel is seen as a living, constantly dynamic, never-sleeping organism: "Is there a moment when there isn't any cigarette lit in the Universal? - the psychologist asked her ironically. No, there isn't any, not even in the early hours, when the noise would quiet down and the sky could be seen for several minutes above the black quadrangle; that's when the concierges who exchanged shifts would light up their first cigarettes. Sometimes, Maia would light the first cigarette when, suddenly awaken, she returned numb with cold from the balcony, ending her automatic vigil with a heating plate brewed hot coffee and a cigarette." ["Exista vreun moment in care nu era nici o țigară aprinsa in Universal? - o întreba psiholoaga, pe un ton ironic. $\mathrm{Nu}$, nu exista, chiar si la primele ore ale dimineții, când vacarmul se potolea si deasupra patrulaterului negru al curții interioare se putea vedea, câteva minute, cerul, in Universal începeau sa-si aprindă primele țigări portăresele care schimbau tura. Uneori, prima țigară o aprindea chiar Maia când, trezindu-se brusc, se întorcea rebegita de pe balcon, punând capăt, cu o cafea fierbinte, fiarta pe reșou, si o țigară, veghii ei automate."] (102) The narrative space includes extended fragments; the character reconstructs events of her existence as a form of release. The atmosphere in the Hotel Universalturned-dormitory is perfectly shaped to the one generated by the state of the society. The idea of privacy is fundamentally dismissed, with the individual melting in a confining uniformity. 
In the novel Un singur cer deasupra lor/ One Heaven Above Them, Ruxandra Cesereanu engages in a painful recollection of a past, differently from Ioana Pârvulescu and Simona Șora. The fiction-cruel reality mix illustrate a grotesque vision of the world. Her memory acts accurately and with a brutality that sometimes astounds the reader, being tributary to the documentary. We find that the author's acknowledgement is relevant; she rejects the idea of a historical novel, thus composing a puzzle-like image of the past age, but sifted through a barely there fictional screen. The use of almost fresh memories, sign of a collective memory that still retained conspicuous stains from the communist period, turns the narrative in a living one or "Memory enables and vitalizes narrative; in return, narrative provides form for memory, supplements it, and sometimes displaces it" (Olney 417). The feeling of textual separation at the reading of the novel is one that is diluted by the diversity of the described topics. Most of the topics that make the textual flesh of the novel were written starting from real events, with characters that give the names of the chapters. Although it has the air of a compilation of stories, the novel comes together also owing to the chronological presentation that starts from the political regime of Gheorghe Gheorghiu-Dej, followed by Ceausescu's regime and then reaching the Revolution and the first post-1989 years. Every character becomes an archetype of communist mythology: "Roby the fugitive had not let the grass grow under his feet: as a foreigner in his own country and in the world in any case, he had decided he had to flee, to run like hell. He knew the name of the shock-headed clandestine hidden on the border, hunted by the border guards and then by the state security, if caught alive. The name of any fugitive who would do that was frontier-prisoner." ["Roby nu rămăsese cu mâinile in sin: ca străin in tara lui si in lume oricum, hotărâse ca trebuie sa o șteargă de aici, sa fuga văzând cu ochii. Știa cum se numea clandestinul cu par vâlvoi, ascuns pe granița, vânat de grăniceri si mai apoi de securiști, daca era prins viu. Numele oricărui fugar care făcea lucrul acesta era acela de frontierist"] (Cesereanu 45) or "The mark of his teeth was on his passport, he had bitten in it, unaware, he had bitten because he was both scared and nauseous. It could no longer be used as a passport, but it could prove who Roby was and from where he came. Roby, full name Robert Oho, came from hell, of course. Where there was no beauty and no truth." ["Pașaportul avea urma dinților lui, caci mușcase din el, fără sa își dea seama, mușcase de frica si de greața la un loc. $\mathrm{Nu}$ mai era bun de nimic ca pașaport, atâta doar ca putea dovedi cine era Roby si de unde venea. Roby pe numele lui întreg Robert. Oho, venea din iad, firește. Acolo unde nu se găsea nici frumusețe, nici adevăr."] (47) To which is added, as a permanent prayer: 
"Pray for me, the sinner!" ["Roagă-te pentru mine păcătosul!"] which recalls the fervor of Steinhardt's faith. The dehumanization conducted by torturers such as the Marquis in Alexandru becomes an example of torture in prisons: "he made the prisoners walk on their knees until the evening came, while they wore crowns as if made of thorns, made from barbed wire" ["îi puse pe deținuți să meargă până seara în genunchi purtând pe cap niște coroane ca de spini, făcute din sârmă ghimpata"] (89), by the destruction of the believers' faith and by their humiliation. The "Pitești experiment" is recalled, at the border between reality and fiction. The collective memory imagines the authority as a satanic one: "Dris, would imagine that the devil looked just that a militia man or like a state security member, like those who had chased him to the train". ["Driș și-1 închipuia pe Dracu' exact ca pe un milițian sau securist dintre cei care-i goniseră la tren."] (25) The apocalyptic imaginary represents God who "should have been a bomb and explode somehow, somewhere, at some point in time. And to turn them all to dust, devils and angels in one place together" ["ar fi trebuit să fie o bombă și să explodeze cumva, undeva, cândva. Și să-i facă praf pe toți, diavoli și îngeri la un loc" $\left.^{\prime \prime}\right]$ (26). The grandfather's guardian figure dominates the chapter Padre Basilio, which is built on documents gathered by the analysis of the file drafted by the State Security for the Greek-Catholic priest Vasile Cesereanu. The range of grotesque events is wide, from portraits such as those of the refugees in the mountains, the Bărăgan deportations, the accusations placed on the intellectuals and their punishment, the "Pitești experiment", the post-1989 mineriads, the orphanages, the individual experiences such as the abortion, the flee on the Danube, the hunger. Women in Ruxandra Cesereanu's prose writings are drawn heavily, sometimes with grotesque emphasis, other times with a touch of ethereal that last only for a few moments, being stifled by the terror of history. Marta Petreu analyzed the meanings of the title, in direct relation to its moral: "The title itself is a story, for I like to believe that the heaven above is the same with Kant's - starry - sky; with the difference that many of Ruxandra Cesereanu's characters were deprived of the second part of the Kantian sentence, of the "moral law within me" ["Titlul însuși e o poveste, căci îmi place să cred că cerul de deasupra este același cu cerul - înstelat - al lui Kant; atâta doar că multe dintre personajele Ruxandrei Cesereanu au fost lipsite de partea a doua a sentinței kantiene, de "legea morală în mine"] (see http://www.revista-apostrof.ro/articole.php?id=2197). There have been discussions about the association of this novel with Varlam Shalamov's Kolyma Tales, the author herself placing her writing under the memory that links, on the one hand, with emotion and, on the other hand, with the credibility offered by 
the information. In the same line with Solzhenitsyn's prose, the writing reconstructs, both by the use of an individual, personal memory and by the casting of fishing net-points, over mnemonic anchors present in all those who lived in the concerned period. Moreover, younger people read instead as fiction the painful transcription of experiences that are equally diverse and defining for a sick society.

Gabriela Adameșteanu also approaches the faults of communism in the novel Provizorat/ Interim. The action placed in Bucharest, during the 1970s, has Letiția Arcan as leading character; her father, Victor Branea was a political prisoner, which thus proved her "unsound origins" which prevented her access to studies and promotion. The described space is the Building and it is the contemporary House of the Free Press and a form of memory that includes a love triangle, with the background of the political situation in the age. Masculine characters are insufficiently articulated, the husband Petre Arcan and the lover Sorin Olaru being marked by some form of schematism, while redundancy generates the reader's distance from the text. "Peter is constantly afraid that he will be condemned because he listens to Radio Free Europe" ["Petru e veșnic speriat că va fi denunțat pentru că ascultă Europa Liberă"] (Adameșteanu 22) The characters surrender to the need of certainty, to an unfathomable fear specific to the totalitarian regime. Peter, who is in an internship in China, launches the sentence that hints at the title of the novel "glass empty in his hand, the signs clearly show that the present good state of things, as it is, is temporary" (262). Women in Gabriela Adameșteanu's prose are frivolous, inconstant, they are either virile or excessively sensual. "They giggle, taught by their blood to hide what's in their minds, to steal each other's men, to be happy that the other one looks now worse than yesterday, to pay each other fake praises, along with the print of pearlescent lipsticks, which are now in fashion, like the eyes heavy with eyeshadow" ["Chicotesc, deprinse prin sânge să ascundă cea au în minte, să-și fure bărbații, să se bucure că cealaltă arată azi mai prost ca ieri, să-și transmită complimente false, o data cu amprenta rujurilor sidefate, la modă, ca și ochii foarte fardați."] (275) The woman's condition is diminished by her physical aspect: "did she risk ending on the scaffold like poor Eleonora, this Marie-Antoinette? Or Mary Stuart or any other queen who, instead of listening to her mind, had listened to her heart and ovaries?" ["risca să ajungă pe eșafod alături de biata Eleonora, această MarieAntoinette? Sau Mary Stuart sau oricare altă regină care, în loc să-și asculte mintea, își ascultase inima și ovarele?"] and "The militia men allow arrests with beatings. How many women had died? Well, we really won't know that, in so 
many decades, hundreds of thousands perhaps, and what about those left without their uterus, without their ovaries..." ["Milițienii dau drumul la arestări cu bătăi. Câte femei au murit? Ei, asta chiar nu vom ști, în atâtea decenii se vor aduna probabil sute de mii, ca să nu mai vorbim despre cele rămase fără uter, fără ovare..."] (286) From this point of view, we note a pattern of human behavior, "to draw attention to the structures of fiction is also to draw attention to the conventionality of the codes that govern human behavior" (Greene 2).

A broken pattern can also be seen in Florina Iliș's Cruciada copiilor/ Children's Crusade. The fast train is an allegory of the Romanian society's transition after 1989; the train, supposed to carry a number of children to the seaside, during the holidays, is hijacked, like in a game, that turns out to be too heavy. They cross the country from Cluj to the seaside; the children, although accompanied by teachers, are led by Calman and the other (the boy obsessed with Harry Potter, there are details on the computer age, such as the recording of the event with a digital camera, the online upload of the actions, by the creation of a website). There are direct references to the post-Revolution conditions that retain the memory of communism, culturally imprinted in the very existence of the Romanian people. That which Maurice Halbwachs called "collective memory" (17) keeps especially elements of culture, while that which Vansina called "communicative memory" (see Oral Tradition as History) retains the importance of the "memories that the individual shares with his contemporaries" (Vansina 112) The memories of the recent past are the narrative magma for the novels that we are discussing in this essay. Sometimes, as with Florina Iliș's text, "the distinction between myth and history vanishes" (Assmann 113), having instead a "cultural memory", i.e. "a kind of institution. It is exteriorized, objectified, and stored away in symbolic forms, that, unlike the sounds of words or the sight of gestures, are stable and situation-transcend: They may be transmitted from one generation to another" (Assmann 110-11). Communicative memory has more elements that belong to the real, to a familiar past for a large number of a society's individuals. The novelist notes, with the words of journalist Pavel Caloian: "Post-revolutionary, so-called democratic regimes, hiding at the core communist mentalities that survive the fall of their maker, are extremely slippery and dangerous in their new and perverted democratic clothes" ["Regimurile postrevoluționare, așa zis democratice, având in structurile de bază mentalități comuniste care supraviețuiesc căderii făuritorului lor, sunt extrem de alunecoase și periculoase în noua și perversa lor înfaţiş,are democratica“"] (Iliș 87) The use of cultural memory occurs by a return to an indefinite time, the essential state being the adjournment: "we are in a 
constant state of adjournment, Romania's history is a history of postponement! as if a country's destiny may be deferred endlessly, you are being rushed, no matter what you do, like with the revolution! But we, the Romanians, we are trained in the school of postponement and of patience, we are forever the history's postponed material! When will we call the shots?!" ["suntem într-o continuă amânare, o istorie a amânării e istoria românilor! de parca destinul unei tări poate fi amânat la nesfârșit, te ia pe sus orice ai face, cum s-a întâmplat și cu revoluția! Dar noi, românii, ne-am format la școala amânării și a răbdării, suntem etern amânații istoriei! Când oare ne vom lua destinul în mâini?!'] (Iliș 285)

The presence of such fragments in the text emphasizes an acute sense of social evolution, a voice of the collective memory that stores the received information, as well as almost mythical transformations of the events, which attain spectacular dimensions. The same period of the transition is illustrated by Ioana Nicolaie's Pasărea pe sârmă / Bird on a Wire, by an eye focused on the fate of Sabina, a student at the Faculty of Letters, in 1992. Together with Eman, she discovers the sordid side of life, the absence of references, a society in decline. "While they talked, they had drunk hot tea in a gangway. At the Revolution, recalled Sabina, they had all believed in rivers of wealth. Everything would be like in the West, good food on the table and clothes that are not made to keep a lifetime. But poverty and inflation would quickly follow. And the miners had spattered a thick film of slime over the new reality. The dirt had crossed through the TV displays in the Occidental news casts" ["Băuseră, în timp ce vorbeau, un ceai fierbinte într-un pasaj. La Revoluție, își aducea aminte Sabina, crezuseră toți în revărsări de bunăstare. Avea să fie ca-n Vest, cu bunătăți pe masa și haine care să nu te țină o viață. Însă îi acoperise imediat sărăcia și inflația. Iar minerii împroșcaseră un strat gros de mâzgă pe noua realitate. Murdăria trecuse prin ecranele televizoarelor în emisiunile de știri occidentale."] (Nicolaie 12) The bitterness of those whose dreams had come apart after the Revolution is analyzed, by the use of communicative or informational memory. Still fresh, memories find their channel by the analysis of a dark period in Romanian history. A Turk's observation is recorded with the artlessness generated by a life in the post- 1990 period, when the freedom of the press is understood in a variety of ways, according to the individual rather than to a community. Memory is built from "influences operating in the present as well as from information stored about the past" (Schacter 8). Here, dimensions are mixed: "In Romania, future like bad shawarma. Cut from it, throw in the bin. Maybe the middle is better" ["La România viitor ca o șaorma stricată. Taie 
la el, aruncă la coș. Miez, poate, e mai bun."] (Nicolaie 89) References to space are built likewise, because every construction keeps the skeleton of the past, on which the present is grafted: "The houses began on the opposite side, they were short, with the same walls in the shade of adobe. Farther away there was a former grocery store, with a sheet metal roof and bars that shook with every opening of the door. A smell of rubbing alcohol should have been felt there and there were definitely imprints on the cement." ["Casele începeau pe partea opusă, scunde, cu aceiași pereți în nuanța chirpiciului. Puțin mai departe era o fostă alimentară, cu acoperiș de tablă și cu zăbrele zdrăngănind la fiecare deschidere-a ușii. Acolo trebuia să miroasă a spirt și pe cimentul de jos sigur se imprimaseră urmele."] (Nicolaie 171) Feelings stir memories of a burdensome past. "She was out in the great square, with the Socialism Victory Avenue slicing that piece of the city and, very far away, with the burden of the People's House. She reached Manuc's Inn, through the rain showered parking" ["Ieși în marea piață, cu bulevardul Victoria Socialismului feliind bucata aceea de oraș și, foarte departe, cu povara Casei Poporului. Pașii o purtară spre Hanul lui Manuc, prin parcarea udă de ploaie."] (Nicolaie 234) Space references are forms of bringing to the fore the informational memory, to provide credibility to the narrative development.

Gabriela Melinescu also writes about Bucharest after 1990, in Acasă, printre străini/ Home, among Strangers, which lends to the female character the voice of the one who returns home, by recollecting the past: "All of a sudden, the time rolled back and I woke up in the streets of Bucharest. It was 1953 and terrible poverty ruled over the city" ["Deodată, timpul s-a răsucit înapoi și mam trezit pe străzile Bucureștiului. Era în anul 1953 și în oraș domneau lipsuri teribile..."] (Melinescu 21) or the Bucharest "was like a resonance chamber for new voices that would mix interminably with the ring of missing voices - sound rebounds that express human feelings. (...) it had not lost the cosmopolitan charm - another invisible city would overlap this one, distorted by the cruelties of history. So: non-time on top of time" ["era ca o cutie de rezonanță pentru noi glasuri care se amestecau necontenit cu timbrul vocilor dispărute - reflectări fonice care dau glas sentimentelor umane.(...) nu-și pierduse atmosfera plină de farmec cosmopolit - un alt oraș, invizibil, se arăta peste acesta, deformat de cruzimile istoriei. Prin urmare: non-timp peste timp"] (234-35). Luli Pelican is the character who betrays, but, an alter ego of the author. The return to Bucharest is not a return to Ithaca, but an arid recording of the absence of ever-awaited changes. "I searched for the street of my childhood. When I found it, I could not recognize it. Everything was so small - the houses were actually buried in the 
ground, the windows, even the roofs had come at ground level, the level of the tomb, the level of death" ["Am căutat strada copilăriei mele. Când am găsit-o, nam mai recunoscut-o. Totul devenise atât de mic - casele erau cu adevărat îngropate în pământ, ferestrele, chiar și acoperișurile ajunseseră la nivelul pământului, al mormântului, al morții"] (224). Memory becomes a form of death, an obliteration of the past that leads to other aspects of fear from the communist period. The fear of informants, which would nourish suspicion among the members of the society, or lead to a schizoid mistrust between friends or relatives, is the symptom of a sick, unsound society. The character remembers, as an obvious porte-parole for the author: "To expose the enemy of the people - this was every citizen's most important duty. I got scared - simply talking about such things, simply listening to them was dangerous. The informants' ears were everywhere. Anyone, a kind neighbor, even a relative could become a rat" ["A demasca dușmanii poporului, aceasta era îndatorirea cea mai de seamă a fiecărui cetățean. Mi s-a făcut frică - era primejdios nu numai să vorbești despre asemenea lucruri, ci chiar și să le asculți. Pretutindeni printre noi se aflau urechile denunțătorilor. Oricine, un vecin amabil, chiar și o rudă, putea să se transforme în turnător."] The return to the past generated an exacerbation of the events, of the situation, seen through the eyes of the present, as future of the discussed past: "Certain events from our past take on extraordinary meaning over time as their significance in the overall story of our lives and times come to be known." (McAdams 45)

A tragic event also is at the core of Doina Ruști's novel Fantoma din moarăl The Ghost in the Mill, in which the fantastic blends with the real, while the cross point is the accidental killing of Maxu, the uncle of Adela, the main character, in Gogu Stănescu's abandoned mill, in the village Comoșteni. The ghost is a pivot of the action, and the fantastic events lead to the unhinging of the village world, itself subject to decline under communism. The family of teachers of which Adela is a member goes into decline, like the village at the center of which they are found. The demolition of the mill in 1986, like the very detailed recording of the ruins of the country houses are signs of a world unable to keep going. From the image of Bucharest, which is often present in contemporary Romanian feminine prose writing, Doina Ruști goes to the formula of the novel that focuses on the rural community, the village dramas, where the central space is the mill. A pretext for the story, the ghost is an efficient narrative construction modality. Covering the span of almost a century, the author uses vague memories from the terrorizing age of communism, from informants to the arrest for abortion or for owning forbidden books. 
In Rău de Românial Romanian Evil, Magda Ursache builds an admissive speech about the 1973-1989 period, a painful memory of a past, through which the character finds that the present is also too cruel, too young to be disrobed of all the faults of the past: "Not long ago, I thought that the only gain of the 1989 event was the freedom of opinion. But I fear that are truths have come to be controlled again." ["Nu demult credeam că singurul cîstig al evenimentului '89 e libertatea opiniei. Mă tem, însă, că adevărurile noastre sînt controlate iarăși"]. Another painful memory that appears in a number of novels that focus on the communist period is the one relating to the "files" regarding the "unsound origins". Iolanda, the female character notes almost journalistically: "A record on each of us, those with unsound origins, was under the watchful eye of the commissions, which examined it as such. I felt the discrimination on my own. Those who had been bourgeois for generations could not be graded objectively" ["Fișa fiecăruia dintre noi, cei cu origine nesănătoasă, se afla sub nasul vigilent al comisiei, care examina ca atare. Am simțit discriminarea pe propria-mi piele. ...". (Ursache 34)

The reading of these novels occurs by appealing to the reader's memory; it is the reading of a fake diary rather than of a book; here, various experiences are listed. The directions of contemporary feminine prose writing, in relation to the past, are thus confirmed, on the one hand by this fresh memory of the recent past, filtered through female sensitivity, and, on the other hand, by the appeal to a cultural memory of the remote past, as in the novels that approach topics about the history of two centuries ago, which may be a topic for a future essay. There are three conclusions that follow from this analysis of the Romanian novel written by women in the post-1989 age. The first one relates to the rejection of a firm, exacerbated feminist attitude that could lead to writings that promote exclusively this movement, beyond the obvious value. Nevertheless, most of the authors experienced a certain "masculine" resistance in the initial reception of the texts, and later the aesthetic criterion was the only one efficient in the evaluation of the novels. The second conclusion is, in fact, the observation regarding the strong shaping of a Romanian feminine prose writing, against a European backdrop, writing that focuses on the communist period and the dramas of women and more, as well-shaped characters of a society that is masculine par excellence and which propose a new vision in South-East Europe literature. The third conclusion regard the recollected space, irrespective of whether it is the public one, given the expanded image of the city or of the village and its variations, or the private one and the constraints placed by the communist regime. Maria Todorova (2014) wrote that European literature 
cannot be appraised without taking into account the literature in the former communist countries. We add that the narrative memories are both a document and a component of national cultures and of European culture. Contemporary Romanian prose written by women is a necessary, primary and important source for the assessment of a past that is part of history. And literature itself makes history.

\section{Acknowledgment:}

Project financed from Lucian Blaga University of Sibiu research grants LBUSIRG-2016-02.

\section{Works Cited}

Adameșteanu, Gabriela. Provizorat. Iași: Polirom, 2010.

Antohi, Sorin and Tismaneanu, Vladimir. Between Past and Future: The Revolutions of 1989 and Their Aftermath. Budapest: Central European UP, 2000. Arendt, Hannah. The Origins of Totalitarianism. London: Harcourt, 1979. Assmann, Aleida. Memory, Individual and Collective. Oxford: Oxford UP, 2006.

Bako, Alina. Reprezentări ale bolii şi maladii ale sistemului socio-politic în romanul românesc. (1960-1980)/ Representations of Diseases and Disorders of the Socio-political system in the Romanian Novel. Bucharest: Editura Muzeul Literaturii Române, 2015.

De la Pola, Ana Lozano. "Gender and Genre in Comparative Literature and (Comparative) Cultural Studies" în Companion to Comparative Literature, World Literatures, and Comparative Cultural Studies. Edited by Steven Tötösy De Zepetnek and Tutun Mukherjee, Cambridge University Press India Pvt. Ltd. under the imprint of Foundation Books, 2013.

Felski, Rita. Literature After Feminism. Chicago: U of Chicago P, 2003.

Funk, Nanette, Mueller Magda. Gender Politics and Post-Communism: Reflections from Eastern Europe and the Former Soviet Union. New York and London: Routledge, 1993.

Halbwachs, Maurice. La memoire collective. Paris: Albin Michel, 1997

Imre, Aniko. "Comparative Central European Culture: Gender in Literature and Film" in Comparative Central European Culture. Ed. Steven Tötösy de Zepetnek. West Lafayette: Purdue UP, 2002, p.71-90.

Iliș, Florina.Cruciada copiilor/ Children's Crusade. Buchrest: Cartea Românească, 2005.

Iser, Wolfgang, The Implied Reader, John Hopkins University Press: 1978. 
Kennedy, Michael D. Envisioning Eastern Europe: Postcommunist Cultural Studies, Ann Arbor: U of Michigan, 1994.

Konrad, Gyorgy. The Melancholy of Rebirth: Essays from Post-Communist Central Europe 1989-1994, Trans. Michael Henry Heim. New York: Harcourt Brace, 1995. Kundera, Milan. Le rideau. Gallimars: Paris, 2005.

McAdams, D. P. The stories we live by: Personal myths and the making of the self. New York: Morrow, 1993.

Melinescu, Gabriela. Acasă, printre străinil Home, among Strangers. Iași: Polirom, 2003.

Moi, Toril. The Feminist Reader: Essays in Gender and the Politics of Literary Criticism. Ed. Catherine Belsey and Jane Moore. New York: Basil Blackwell, 1989.

Nalbantian, Suzanne. Memory in Literature: From Rousseau to Neuroscience. Palgrave Macmillan, 2003.

Nicolaie, Ioana. Pasărea pe sârmă/ Bird on a Wire. Iași: Polirom, 2008.

Pârvulescu, Ioana. Inocenții/ The Innocents. Bucharest: Humanitas, 2016.

Ricoeur, Paul. La mémoire, l'histoire, l'oubli. Paris: Editions du Seuil, 2000.

Ruști, Doina. Fantoma din Moară/ The Ghost in the Mill. Iași: Polirom, 2008.

Schacter, Daniel L. Searching for Memory: The Brain, the Mind, and the Past. New York: HarperCollins, 1996. Print.

---. The Seven Sins of Memory: How the Mind Forgets and Remembers. Boston: Houghton Mifflin, 2001.

Smith, Sidonie. A Poetics of Women's Autobiography: Marginality and the Fictions of Self-Representation. Bloomington: Indiana UP, 1987.

Sontag, Susan. Regarding the Pain of Others. New York: Farrar, Straus and Giroux, 2003.

Șora, Simona, Hotel Universal. Iași: Polirom, 2012.

Terian, Andrei. "National Literature, World Literatures, and Universality in Romanian Cultural Criticism 1867-1947." CLCWeb: Comparative Literature and Culture 15.5 (2013): <http://dx.doi.org/10.7771/1481-4374.2344>.

Todorova, Maria, Dimou, Augusta, Troebst, Stefan, Remembering Communism: Private and Public Recollections of Lived Experience in Southeast Europe. Budapest: Central European University Press, 2014.

Tolan, Fiona. Feminisms.' Literary Theory and Criticism: An Oxford Guide. Oxford: Oxford University Press, 2006. 319-339.

Tötösy de Zepetnek, Steven. "Configurations of Postcoloniality and National Identity: In-between Peripherality and Narratives of Change." The Comparatist: Journal of the Southern Comparative Literature Association 23 (1999): 89-110. 
Tötösy de Zepetnek, Steven. Comparative Central European Culture. Purdue: Purdue UP, 2002.

Tötösy de Zepetnek, Steven. “Women's Litterature and men Writing about Women" in Comparative Literature: Theory, Method, Application. By Steven Tötösy de Zepetnek. Amsterdam-Atlanta, GA: Rodopi, 1998. p.173-214

Ursache, Magda. Rău de Românial Romanian Evil. Iași: Editura „Junimea”, 2003.

Vansina, Jan. Oral Tradition as History. Madison: U of Wisconsin P, 1985.

Wieviorka, Michael. La différence. Paris: Éditions Balland, 2001.

*** Cum citesc bărbații cărțile femeilor/ How Men Read Women's Books. volume coordinated by Lia Faur and Șerban Axinte, Iași: Polirom, 2017.

***Tovarășe de drum. Experiența feminină în comunism/ Female Fellow Travelers. Feminine Experience in Communism. volume coordinated by Radu Pavel Gheo, Dan Lungu, Iași: Polirom, 2008. 